Article

\title{
The Influence of Performance-Based Building Design on the Strategy of Retail Property in Indonesia
}

\author{
Sulfiah Dwi Astarini *, Christiono Utomo *(1), Ayu Fatimah Sari, M Arif Rohman \\ and Nugroho Priyo Negoro \\ Department of Civil Engineering, Institut Teknologi Sepuluh Nopember, Surabaya 60111, Indonesia; \\ Ayufatimahsari95@gmail.com (A.F.S.); arif.its@gmail.com (MA.R.); npriyo.negoro@gmail.com (N.P.N.) \\ * Correspondence: sulfiahdwiastarini@gmail.com (S.D.A.); christiono@ce.its.ac.id (C.U.)
}

Received: 16 September 2020; Accepted: 19 October 2020; Published: 23 October 2020

\begin{abstract}
Management of retail property is important in accommodating tenants who occupy retail space and consumers as a retail property business activity. Performance-based Building Design (PBBD) is a concept that can be used in planning and designing so that retail buildings can operate as expected. In this regard, the strategy of retail space contains three indicators of performance that are effectiveness, profitability, and efficiency. This study finds gaps in retail property management design research. Therefore, the purpose of this study is to determine the effect of PBBD application on the strategy for retail property space in Indonesia. A total of 96 respondents were involved in this study. Data were collected through a questionnaire survey to stakeholders who play a role in the development and management of the retail property in Surabaya. The data were then analyzed using multiple regression. From the analysis, it was found that the application of PBBD, namely user/occupant interest, building management, the process of design collaboration had a positive effect, while the risk of loss had a negative effect. This means that the increased application of PBBD, namely occupant interest, building management, the process of design collaboration and reduced risk of loss in retail buildings, can improve the strategy for managing retail property space in Surabaya, Indonesia. A more detailed analysis of each indicator of the retail space strategy shows different results. The result show that the application of PBBD influence to the effectiveness contributes $44.6 \%$, the influence of PBBD application to the profitability contributes $49.4 \%$, the application of PBBD has an influence for the efficiency by $61.5 \%$, and overall, the influence of PBBD application to the management retail property space contributes $68.9 \%$. The results of this research are very important and have implications for retail space planning strategies. What will happen to retail property management at the operational stage, it can be seen through the implementation of PBBD in the briefing and planning stages.
\end{abstract}

Keywords: performance-based building design; retail property space strategy; design building; retail property; Indonesia

\section{Introduction}

Property is a space and place business whose management is an important factor for the success of the retail property business. The existence of retail property is an activity to sell goods and services that can increase consumer associations in an area [1]. Not only as a place of sale, but retail property is also a place for consumers to get information about new products, so that consumers feel satisfied and decide to buy the product [2]. Thus, the role of retail property in meeting customers has the opportunity to increase store reputation. Nourse [3] shows that the performance of property management in strategic planning for retail property space can be measured by three indicators, namely effectiveness, profitability, and efficiency. 
Based on Table 1, retail commerce usage $100 \%$ amounts to 30 retail stores with a maximum operating age of 2-10 years. The operational status of active retail stores is 32 , with occupancy rates at $>70 \%$. The total gross area of retail buildings in Surabaya is 1.2 million hectares. With a high number of occupancy rates, it is appropriate to pay more attention to planning the management of a retail property space strategy within accommodating tenants and creating a pleasant shopping experience for consumers at the malls Surabaya, Indonesia.

Furthermore, the starting point of this study is to determine the effect of application PBBD on strategic planning for retail property space in Surabaya. A total of 96 respondents were involved consisting of project managers, designers, and property managers. Data were collected using a questionnaire and then analyzed using regression analysis. This research is a development from previous research [8]. Thus, this paper can contribute not only to increasing theoretical knowledge, but also in providing an optimal design strategy for retail property.

\section{Literature Review}

\subsection{Performance-Based Design in Property Development}

Property development in the construction industry can be considered similar to the production process from other industries which consists of various combinations to produce a product [9]. The property development process starts from feasibility, project concept with output feasibility analysis, project management, marketing and disposal [10]. These processes are usually interrelated in the completion of property development and have their respective complexities at each stage [11]. One of the complexities in a property development project comes from stakeholders who have different needs, interests and concerns that can negatively or positively affect the project [12]. Other challenges such as environmental, economic, and social factors generated by buildings make developers increasingly need design and construction experts to produce high-performing buildings. Performance of the buildings require a design process that can create innovative activities even though their performance activities can be difficult to assess and measure [13]. Therefore, in the area of design performance, then appear terms of product performance and process performance [14]. Product performance is defined as a product in accordance with client expectations, while process performance is defined as all activities carried out with consideration of cost, time, and quality [13].

The design approach starts by determining the required performance targets and then selecting the system from the best design solution [15]. Generally, the performance approach is emphasized more like a business problem than a technical problem. This is because from the demand side, the performance approach focuses on meeting the needs and requirements of those who own the building or use the building. The requirements from stakeholders are more dominant to be communicated to know the benefits of implementing performance and have an actual value on the building [16]. The implementation of the performance approach will be successful if all stakeholders involved in the project—owners, designers, building supervisors, and the government-are aware of risks and can work together, so that all can reach a common understanding [17].

\subsection{Property Management}

Yiu and $\mathrm{Xu}$ [18] show that there is a positive relationship between the floor area of a shopping center and the type of retail tenant measured in square feet. For example, the estimated gross floor area of 500,000 square feet can accommodate as many as 30 types of retail tenants. Optimization of retail tenants in shopping malls is very important because there is a strong relationship between mall size and the number of retail tenants. A large mall size with few tenants and a small mall size with many tenants gives the same result, which is showing ineffective management performance, even though the resulting profitability is different.

In terms of profitability aspect, it can be seen by looking at the role of retail property management in its relationship with consumers and retailers. In its operation, retail mall managers must be able 
to design the atmosphere, facilities, and services of the mall according to consumer preferences in providing entertainment and needs. Since the competition between retail malls increases over time, making mall managers try to carry out promotions to attract customers to achieve profits. For retailers, retail malls must provide sales support facilities and systems for retailers in conducting business. It is because by providing these services is expected to be an advantage for their sale [19].

According to [20], the design of retail property aims to improve financial performance and minimize maintenance costs. Financial performance includes profits as measured by turnover per square foot (meters), sales in linear space, stock turnover rates, and return on sales [21]. For the efficiency of retail property maintenance costs related to its management, namely as an investment asset and as an operational asset. Management of investment assets is expected to return capital, while operational assets are expected to support business activities, this is usually referred to as company property [22]. Increasing retail arrangements such as providing efficient space, layout and promotions are highly emphasized by tenants to gain consumer interest in visiting malls.

Owning property aims as an investment and/or as an operating asset. Retail mall strategy planning and business models using the facility asset planning and maintenance approach are directly related to each other [23]. Property management is the activity of managing and maintaining buildings and facilities at the operational level. In this case, the property manager maintains and/or increases the value of the building, creates a safe, functional, conducive environment for users and enhances the right image of the building so that these activities bring optimal benefits to the owner [24].

\subsection{Space Strategy of Retail Property}

The allocation of space for shopping malls refers to the division of retail tenants into various categories of stores. One of the most important parts that can influence the success of a shopping mall is placing retail store tenants and their combinations with several other retail stores [25], because it can affect the flow of consumer [26], and stimulate consumer purchases [27]. Basically, retailers as tenants first consider support in providing goods or services to consumers before retailers occupy and use their property space for retail purposes. Investors also do the same thing to invest in retail property in the hope of getting demand from retailers as users of retail space [28].

One of the influences in stimulating consumer purchases is the existence of an anchor store. Damian et al. [29] investigated the impact of the presence of an anchor store on shopping malls in Portugal. An anchor store is a unit within a shopping center with various tenants. This anchor store is usually $\geq 600 \mathrm{~m}^{2}$ in size, has branches that are spread nationally and internationally, has a strong brand, an independent section, and has a special position related to rental and service fees. The result of research [29] shows that the presence of an anchor store can directly increase sales and customer attractiveness, not only to their store, but also to other stores. For example, other large tenants benefit from paying low rents, while smaller shops get increased demand from customers and pay relatively high rents.

The research by [25] which explores space allocation related to store size and tenant placement by type and location in shopping malls in Hong Kong. Stores with a large size and as the main tenants are more likely to be allocated on the upper floors of the shopping mall building, this is to encourage customers to reach higher floors, except for department stores which are usually located on the lower floors. The placement of non-impulse retail store tenants is also in the same location to get positive influence from customers.

According to [30] make a pleasant experience for consumers in a retail store is as important as space for interactivity, socialization, and communication. El Hedhli et al. [31] added as a place for recreation. Altuntas [32] using the high-utility itemset mining (HUIM) approach algorithm for structuring store layouts based on customer consumption habits in a case study at a supermarket. The results show that store layout is an important business strategy because it affects business success and service of efficiency. Buttle [21] divides retail space allocation into five aspects, there are: (1) The location of sales support equipment, for example, a gondola, (2) the location of the product category, (3) the location of 
the goods in the product category, (4) the display outside the shelf and (5) promotional support such as point-of-sale.

\subsection{Application of PBBD and Its Relationship with Building}

\subsubsection{Users/Occupants Interest}

The buildings that are designed will eventually be used or occupied by end-users. Therefore, user/occupant interests are the main priority because it relates to occupants' or users' satisfaction. In terms of occupant satisfaction, Mostavi et al. [33] developed an optimization model for the thermal design of a building by minimizing life cycle cost (LCC) and life cycle emission (LCE). Thermal comfort, which is suitable room temperature, can improve the assessment of indoor environmental quality. On the other hand, Baek et al. [34] verify the hypothesis in investigating the effect of store design that provides visual warmth, thus influencing users as consumers in increasing store intimacy. Similar to the research [35] that investigated retail lighting and its effects on human perception using a simulation-based, subjective approach in the sales area. The importance of providing a shopping experience for consumers is also indicated by [21] that use a separate gondola layout with no secondary hallway, can increase sales and more efficient use of floor space. Retail environmental problems can bother the performance and welfare of customers. Therefore, the optimization of indoor environmental conditions is very important to maximize customer satisfaction in a retail space environment.

\subsubsection{Building Management}

Building management is defined as the process of supervising and managing a building in accordance with the owner's goals, procedures, business activities, etc. [36]. In building maintenance, there are two categories based on the performance of maintenance namely asset management and building maintenance management, both of which require a budget in the process of their activities [37]. In achieving optimal building asset management, Al-Kasasbeh et al. [38] developed a work breakdown structure (WBS) to assess and predict damage in the building asset classification system. Salazar and Calcedo [12] conducted a qualitative analysis using fuzzy to see the effect of building management intensity and cost analysis at the health center. Hui [39] identifies problems related to building management in residential areas with the aim of being able to understand the relationship between owners and building management companies in dense residential areas. Xie et al. [40] used augmented reality (AR) to detect environmental anomalies to assist facility managers in overcoming problems that can affect the thermal comfort of building occupants. However, in building maintenance and management it is important to ensure optimal performance during its life cycle. This process must be carried out by the developer efficiently in order to avoid complaints by building users/occupants [41].

\subsubsection{Process of Design Collaboration}

Designing a performance building requires collaboration in sharing ideas and knowledge between stakeholders involved in the project. De'tienne et al. [42] assesses the effectiveness of the collaboration in producing a successful design. However, in the design process, one of them is inseparable from time, Mcharek et al. [43] developed multidisciplinary design optimization (MDO) to accelerate the design process and support designers during this stage of the design cycle. Interdisciplinarity is involved during the collaboration process, by making regular communication among several stakeholders. For that [44] reviews the literature and describes the application of virtual reality (VR) which has the potential to complement communication and facilitate the digitalization of the architecture, engineering, and construction (AEC) industry. In line with [45] also explore communication and e-negotiation practices in collaboration to get the best designs. Of course, the support of mutual trust can also increase collaboration among project participants [46]. Kent [30] mentioned that the retail design process that involves a wide range of stakeholders can enhance creative thinking to connect retailers and consumers. 


\subsubsection{Risk of Loss}

Building code regulations have shifted from prescriptive to performance-based, so that the development of technological tools in designing safety is required [47]. Within design retail buildings, safety factors related to uncertainty in the building have been used in engineering safety and fire safety. Preventing and reducing damage due to extreme disasters is a concern in assessing the risk of loss and damage [48]. One of the disasters is a fire that can cost significant property and life. Residents can reduce the risk of loss if they can quickly protect their property. Penman et al. [49] develop a property resilience model by looking at construction, design and building materials. Kobes et al. [50] developed a literature review on human behavior in fire safety. It is clear although the structure of the building has been best designed according to strict standards and practices, the possibility of failure or collapse of the building due to a catastrophic event such as an earthquake cannot be avoided. It is due to the nature of the material and/or the soil in which it is composed [51].

This research is directed to support the following hypothesis. First, this research tries to show that the strategy of retail property space related to the proportion of leased space is influenced by the implementation of PBBD. Therefore, Hypothesis 1 is as follows:

Hypothesis 1 (H1). The application of PBBD can increase the effectiveness in planning strategies for retail property space.

Second, this study aims to prove that the strategy for retail property space in terms of the ability to generate income is influenced by the application of PBBD. So, Hypothesis 2 is:

Hypothesis 2 (H2). The application of PBBD can increase profitability in strategic planning for retail property space.

Third, this study aims to show that strategic planning for retail property space related to maintenance operational costs is influenced by the implementation of PBBD. Hypothesis 3 is therefore formulated as follows:

Hypothesis 3 (H3). The application of PBBD can increase efficiency in strategic planning for retail property space.

Finally, this study tries to show that the application of PBBD can improve the overall retail property space strategy. Hypothesis 4, namely:

Hypothesis 4 (H4). The application of PBBD can increase the achievement of a retail property space planning strategy. Figure 1 shows the relationship of variable model used.

The Table 2 is then shown to see the position of this research development. The table used is adopting the research [52] to describing the contributions of various authors.

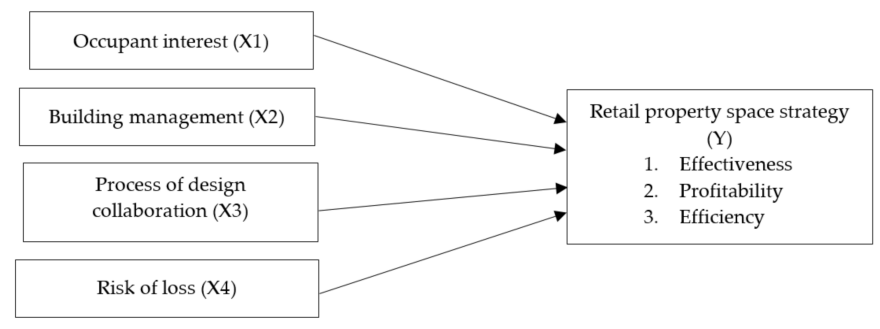

Figure 1. The conceptual model relationship of performance-based building design with retail property space strategy. 
Table 2. Research development.

\begin{tabular}{|c|c|c|c|c|c|c|c|c|c|c|}
\hline \multirow[b]{2}{*}{ Author(s) } & \multicolumn{3}{|c|}{ Performance Management Property } & \multicolumn{4}{|c|}{ Construction Stages } & \multicolumn{3}{|c|}{ Performance Design } \\
\hline & Effectiveness & Profitability & Efficiency & Planning & Designing & Operational & $\begin{array}{l}\text { Occupant } \\
\text { Interest }\end{array}$ & $\begin{array}{c}\text { Building } \\
\text { Management }\end{array}$ & $\begin{array}{c}\text { Process of } \\
\text { Design } \\
\text { Collaboration }\end{array}$ & Risk of Loss \\
\hline [1] & & - & & & & & & - & & \\
\hline [2] & & & & & & $\bullet$ & $\bullet$ & & & \\
\hline [3] & & $\bullet$ & & & & & & & & \\
\hline$[4]$ & & & & & • & & • & & & \\
\hline [5] & & & & & & • & $\bullet$ & & & \\
\hline [6] & - & & & & - & & $\bullet$ & $\bullet$ & & \\
\hline$[7]$ & & & & & - & & & & & \\
\hline [8] & & & & & & & $\bullet$ & $\bullet$ & $\bullet$ & $\bullet$ \\
\hline [9] & & & & & & & & & & - \\
\hline [11] & & $\bullet$ & & & & & & & & $\bullet$ \\
\hline [12] & & & • & & & • & & $\bullet$ & & \\
\hline$[13]$ & & & & & - & & & & & \\
\hline [14] & & & & & $\bullet$ & & & & $\bullet$ & \\
\hline$[15]$ & & & & & $\bullet$ & & & & & • \\
\hline$[16]$ & & & & & - & & & & • & \\
\hline [17] & & & & & & • & & • & & \\
\hline [18] & • & & & & & - & & & & \\
\hline [19] & & • & • & & & & • & • & & \\
\hline [20] & • & & & & • & & & & & \\
\hline [21] & & & & • & & & • & & & \\
\hline [23] & • & • & & & & & & • & & \\
\hline [24] & • & $\bullet$ & • & & • & & & & & \\
\hline [25] & - & & & & - & & & & & \\
\hline [26] & & & & & & • & & • & & \\
\hline [27] & • & • & & & & - & & & & \\
\hline [28] & • & • & & & & • & & & & \\
\hline [29] & & & & & • & & • & & & \\
\hline [30] & & & & & & • & & • & & \\
\hline [31] & & & • & & & • & • & - & • & \\
\hline [32] & & & • & & & • & & & & \\
\hline [33] & & & & & • & & • & & & \\
\hline
\end{tabular}


Table 2. Cont

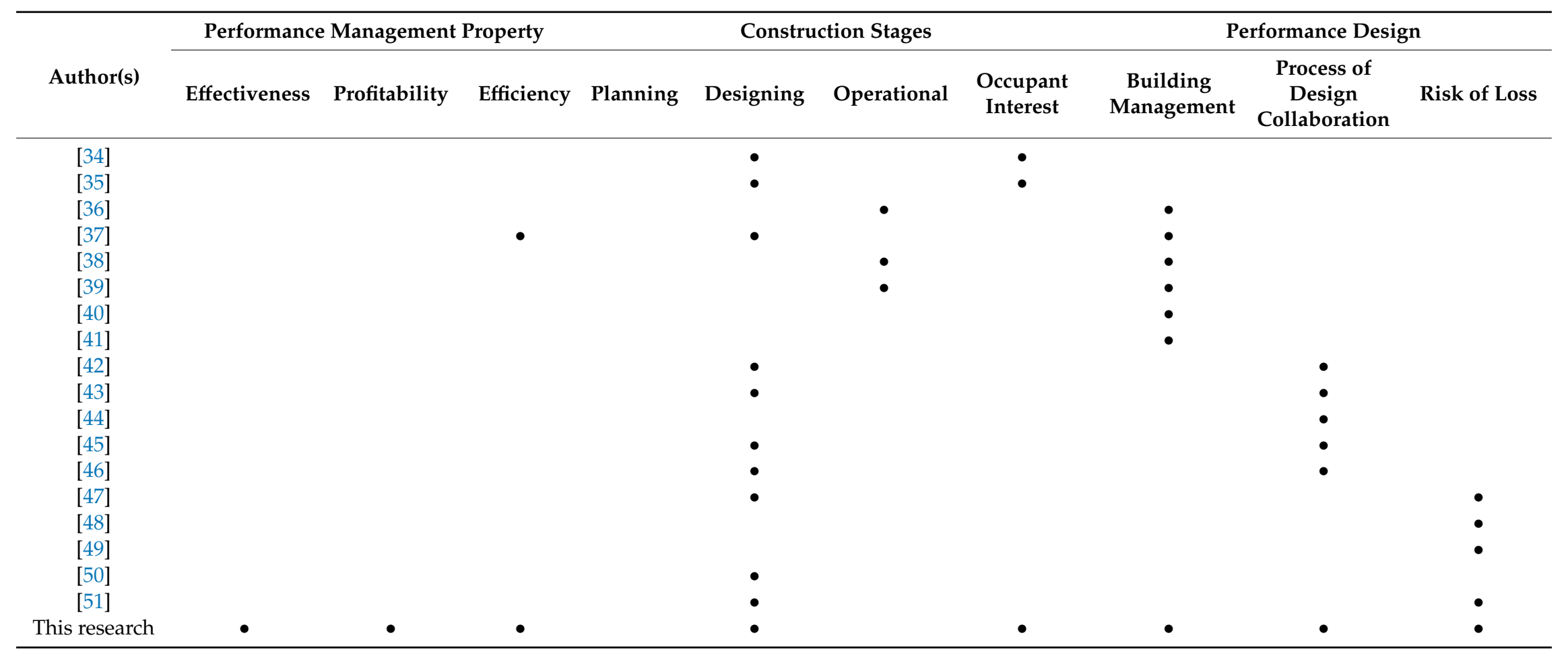




\section{Research Methods}

\subsection{Sampling and Data Collection}

The survey was conducted in Surabaya and involving 96 respondents consisting of project managers, designers, and property managers. The project manager is the one who leads the project development from the design stage to the handover with the retail property manager. A designer is a person who plans and develops design. The property manager is the person who manages the retail property. Respondents' experiences were then grouped into three parts, namely: Juniors experience $<5$ years, seniors $>15$ years and middle in between. The data of the respondents can be seen in Figure 2.

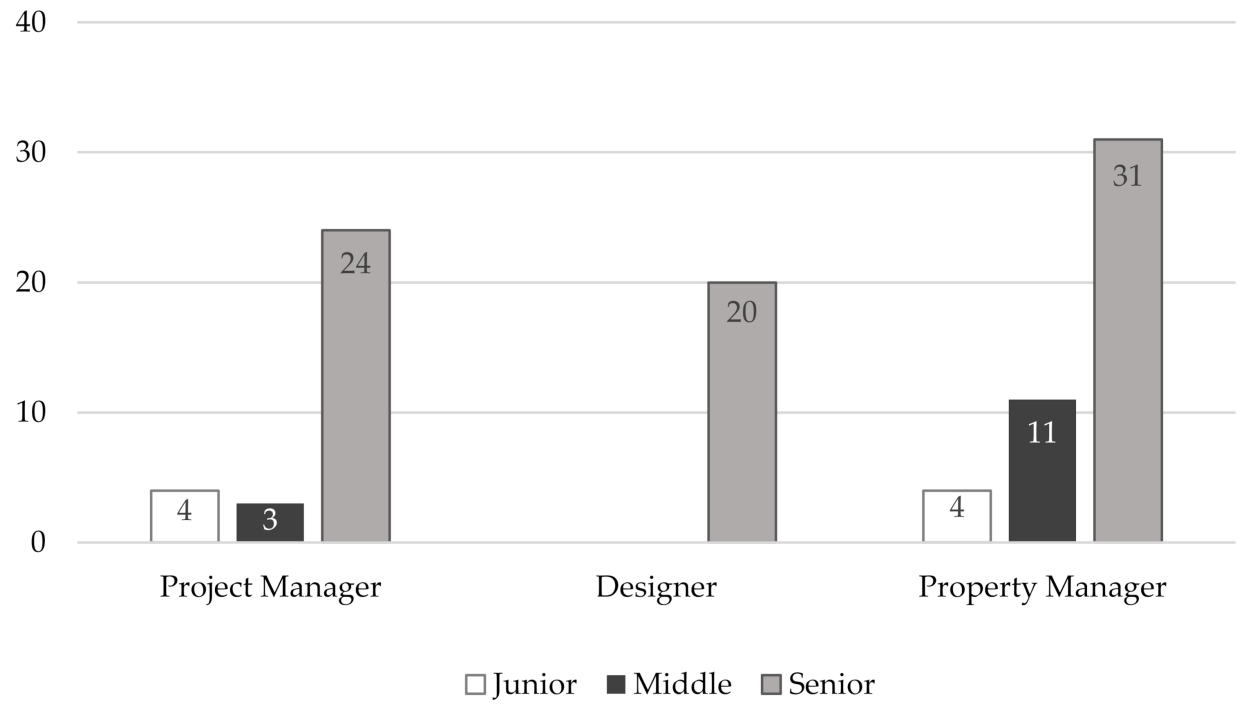

Figure 2. Data of respondent.

This study uses a scale, that is the Likert scale to assist in the conceptualization and operational processes. The Likert scale is also used in survey research [53] and called the summation scale because the score obtained from the respondent is calculated by adding up the scores for the responses given. The Likert scale request to respondents indicates whether respondents agree with a statement. In this study, a 5-point Likert scale was used with the value given, namely a value of $1=$ strongly disagree, $2=$ disagree, $3=$ neutral, $4=$ agree, $5=$ strongly agree. Data were collected using a questionnaire to observe the effect of PBBD application on the strategy for retail property space in Surabaya based on the perceptions of retail property players.

\subsection{Data Analysis Method}

To determine the effect of the independent variable on the dependent variable, data were calculated and modeled using multiple regression analysis. Multiple regression is a statistical technique used to analyze the relationship of one criterion or dependent variable and several predictor or independent variables. The purpose of multiple regression analysis is to use the value of the independent variable in predicting the value of the dependent variable chosen by the researcher [54]. The form of the multiple regression equation is as follows:

$$
Y=\alpha+\beta_{1} X+\beta_{2} X 2+\beta_{3} X 3+\ldots+\beta_{N} X_{N}
$$

where $\mathrm{Y}$ is the criterion variable (dependent), $\alpha$ is a constant value, when all (independent) predictor variables are at $0, \beta_{1} \ldots \beta_{N}$ is the value of the regression coefficient and $X_{1} \ldots X_{N}$ is a predictor variable (independent). 


\section{Result and Discussion}

\subsection{Validity Test}

The purpose of the validity analysis used in this study is to measure the validity or suitability of the instruments used in obtaining information from respondents or research samples. The measurement of validity reveals how well the conceptual and operational definitions are related to one another, the better the match, the higher the validity of the measurement [53]. The results of the validity analysis for each construct are shown in Table 3.

Table 3. Validity and reliability analysis.

\begin{tabular}{ccc}
\hline Variable & Validity & Reliability \\
\hline User/occupant Interest & 0.501 & 0.777 \\
Building management & 0.622 & 0.759 \\
Process of design collaboration & 0.666 & 0.759 \\
Risk of loss & -0.480 & 0.895 \\
Effectiveness & 0.865 & 0.735 \\
Profitability & 0.865 & 0.735 \\
Efficiency & 0.851 & 0.729 \\
Retail property space strategy & 1.000 & 0.706 \\
\hline
\end{tabular}

\subsection{Reliability Test}

The purpose of the reliability analysis in this study is to measure the consistency or stability of the questionnaire data, or in other words to find out which instruments are used in obtaining reliable information based on different time periods [53]. A value that shows $>0.7$ means that the construct is reliable [54]. Internal consistency with Cronbach's alpha value was used in this study and the results of the reliability analysis are shown in Table 3.

\subsection{Regression Analysis}

To test the influence relationship between the dependent variable and the independent variable, a regression model analysis was conducted to see the effect of PBBD application factors on retail property space in Surabaya. The coefficient of determination $\mathrm{R}^{2}$ is to test how big the prediction of the percentage variation in the dependent variable is explained by all the included independent variables. Table 4 summary model for the relationship of PBBD application to the effectiveness, profitability, and efficiency of retail space.

Table 4. Model summary of effectiveness, profitability, and efficiency.

\begin{tabular}{ccccc}
\hline Model & R & R Square & Adjusted R Square & Std. Error of the Estimate \\
\hline 1 & $0.668^{\mathrm{a}}$ & 0.446 & 0.422 & 0.756 \\
2 & $0.703^{\mathrm{b}}$ & 0.494 & 0.471 & 0.785 \\
3 & $0.784^{\mathrm{c}}$ & 0.615 & 0.598 & 0.669 \\
\hline
\end{tabular}

a,b,c Predictors: (Constant), Risk of Loss, Building Management, Occupant Interest, Process of Design Collaboration. Dependent Variable: Space of strategy retail property.

From Table 4 , the $\mathrm{R}^{2}$ value for model 1 is $44.6 \%$. This means that all the independent variables analyzed, namely occupants' interest, building management, process of design collaboration and risk of loss contributed $44.6 \%$ in increasing the effectiveness of the retail property space strategy in Surabaya. Meanwhile, $55.4 \%$ is another factor that was not examined in this study. Model 2 contributes $49.4 \%$ in increasing the profitability of the retail property space strategy in Surabaya. Meanwhile 50.6\% is another factor not examined in this study. Finally, in the third model, the R2 value is $61.5 \%$. This means that all the independent variables analyzed contributed $61.5 \%$ in increasing the efficiency of the retail 
property space strategy in Surabaya. Meanwhile $38.5 \%$ is another factor that was not examined in this study. Furthermore, the results of the regression analysis are shown in Table 5.

Table 5. The coefficients of dependent variable: effectiveness, profitability, and efficiency.

\begin{tabular}{|c|c|c|c|c|c|c|c|c|}
\hline \multirow{2}{*}{\multicolumn{2}{|c|}{ Model }} & \multicolumn{2}{|c|}{$\begin{array}{l}\text { Unstandardized } \\
\text { Coefficients }\end{array}$} & \multirow{2}{*}{$\begin{array}{c}\begin{array}{c}\text { Standardized } \\
\text { Coefficients }\end{array} \\
\text { Beta }\end{array}$} & \multirow[t]{2}{*}{$\mathbf{t}$} & \multirow[t]{2}{*}{ Sig. } & \multicolumn{2}{|c|}{ Collinearity Statistic } \\
\hline & & B & Std. Error & & & & Tolerance & VIF \\
\hline \multirow{5}{*}{1} & (Constant) & 1.367 & 0.636 & & 2.149 & 0.034 & & \\
\hline & User/occupant Interest & 0.071 & 0.080 & 0.077 & 0.887 & 0.378 & 0.815 & 1.227 \\
\hline & Building Management & 0.329 & 0.077 & 0.363 & 4.250 & 0.000 & 0.834 & 1.199 \\
\hline & Process of Design Collaboration & 0.430 & 0.105 & 0.361 & 4.078 & 0.000 & 0.778 & 1.286 \\
\hline & Risk of Loss & -0.099 & 0.089 & -0.096 & -1.102 & 0.273 & 0.809 & 1.236 \\
\hline \multirow{5}{*}{2} & (Constant) & 1.197 & 0.661 & & 1.812 & 0.073 & & \\
\hline & User/occupant Interest & 0.259 & 0.083 & 0.256 & 3.104 & 0.003 & 0.815 & 1.227 \\
\hline & Building Management & 0.307 & 0.080 & 0.311 & 3.812 & 0.000 & 0.834 & 1.199 \\
\hline & Process of Design Collaboration & 0.361 & 0.109 & 0.279 & 3.297 & 0.001 & 0.778 & 1.286 \\
\hline & Risk of Loss & -1.163 & 0.093 & -0.146 & -1.756 & 0.082 & 0.809 & 1.236 \\
\hline \multirow{5}{*}{3} & (Constant) & 0.646 & 0.563 & & 1.146 & 0.255 & & \\
\hline & User/occupant Interest & 0.154 & 0.071 & 0.156 & 2.168 & 0.033 & 0.815 & 1.227 \\
\hline & Building Management & 0.307 & 0.069 & 0.319 & 4.486 & 0.000 & 0.834 & 1.199 \\
\hline & Process of Design Collaboration & 0.562 & 0.093 & 0.445 & 6.031 & 0.000 & 0.778 & 1.286 \\
\hline & Risk of Loss & -0.175 & 0.079 & -0.160 & -2.210 & 0.030 & 0.809 & 1.236 \\
\hline
\end{tabular}

From Table 5 the equation is obtained:

$$
\begin{aligned}
& Y_{1}=1.367+0.71 X_{1}+0.329 X_{2}+0.430 X_{3}-0.099 X_{4} \\
& Y_{2}=1.197+0.259 X_{1}+0.307 X_{2}+0.361 X_{3}-1.163 X_{4} \\
& Y_{3}=0.646+0.154 X_{1}+0.307 X_{2}+0.562 X_{3}-1.175 X_{4}
\end{aligned}
$$

From the above equation, it can be seen that each of the strategies for retail property space, namely effectiveness, profitability, and efficiency, is positively influenced by occupant interests, building management and design collaboration, and is negatively affected by the risk of loss.

Furthermore, re-analysis is carried out to see the effect of PBBD application on the overall retail property space strategy. The model summary is shown in Table 6.

Table 6. Model Summary of strategy property retail.

\begin{tabular}{ccccc}
\hline Model & $\mathbf{R}$ & R Square & Adjusted R Square & Std. Error of the Estimate \\
\hline Retail property space strategy & $0.830^{\text {a }}$ & 0.689 & 0.676 & 0.51094 \\
\hline a Predictors: (Constant), Risk of Loss, Building Management, Occupant Interest, Process of Design Collaboration. \\
Dependent Variable: Retail property space strategy.
\end{tabular}

The $\mathrm{R}^{2}$ results for the retail property space strategy model of $68.9 \%$ mean that all independent variables, namely occupant interest, building management, the process of design collaboration and risk of loss contributed $68.9 \%$, while other factors not examined in this study contributed $31.1 \%$. Further regression analysis is shown in Table 7.

The equation is obtained from Table 7:

$$
\mathrm{Y}=1.070+0.161 \mathrm{X}_{1}+0.314 \mathrm{X}_{2}+0.451 \mathrm{X}_{3}-0.146 \mathrm{X}_{4}
$$

From this equation, it is shown that occupant interest, building management and process of design collaboration have a positive effect, while risk of loss has a negative effect. This means that implementing PBBD, occupant interest, building management, process of design collaboration and reducing risk of loss can improve retail property space strategies. 
Table 7. Coefficients of dependent variable: strategy property retail.

\begin{tabular}{|c|c|c|c|c|c|c|c|}
\hline \multirow{2}{*}{ Model } & \multicolumn{2}{|c|}{$\begin{array}{c}\text { Unstandardized } \\
\text { Coefficients }\end{array}$} & \multirow{2}{*}{$\begin{array}{c}\text { Standardized } \\
\text { Coefficients }\end{array}$} & \multirow[t]{2}{*}{$\mathbf{t}$} & \multirow[t]{2}{*}{ Sig. } & \multicolumn{2}{|c|}{ Collinearity Statistic } \\
\hline & B & Std. Error & & & & Tolerance & VIF \\
\hline (Constant) & 1.070 & 0.430 & & 2.488 & 0.015 & & \\
\hline Occupant Interest & 0.161 & 0.054 & 0.192 & 2.972 & 0.004 & 0.815 & 1.227 \\
\hline $\begin{array}{c}\text { Building } \\
\text { Management }\end{array}$ & 0.314 & 0.052 & 0.384 & 6.004 & 0.000 & 0.834 & 1.199 \\
\hline $\begin{array}{l}\text { Process of Design } \\
\text { Collaboration }\end{array}$ & 0.451 & 0.071 & 0.419 & 6.331 & 0.000 & 0.778 & 1.286 \\
\hline Risk of Loss & -0.146 & 0.060 & -0.156 & -2.407 & 0.018 & 0.809 & 1.236 \\
\hline
\end{tabular}

Based on Tables 4 and 6, a multicollinearity test has been carried out by looking at the Tolerance and Variance Inflation Factor (VIF) values. The purpose of multicollinearity test is to see the correlation of the independent or independent variables in the regression model. If the independent variable shows collinearity, the value is 0 and the collinearity value 1 means a lack of collinearity. The VIF factor is also directly related to the tolerance value, where a large VIF value also indicates that there is collinearity or multicollinearity between the independent variables [54]. From the multicollinearity test results in this study, it can be concluded that there is no multicollinearity between the independent variables.

Planning a retail mall that provides stores with a wide variety of goods and services needs to contribute to improving consumer welfare and benefits for tenants. Include the user/occupant interests in strategic planning for retail property that can improve the performance of the property space, one which is convenience related to social performance such as visual comfort and indoor air comfort. The comfort is perceived by consumers as users increase well-being in shopping and affect consumer behavior towards store reputation. Poor indoor temperature can lead to disease, this is also highlighted by [33].

Planning a retail property space is also inseparable from its management. The management of a retail mall aims to increase consumer attractiveness to shop. The proper management of retail property space is not strong enough to be able to compete with other retail property, including in fulfilling customer satisfaction. The provision of attributes such as entertainment at retail malls is as unlimited as possible, thus creating advantages for consumers. The strategy of managing retail property space is an important business activity and has an effect on the success of its operations. A retail mall consists of a group of retailers located in one building and managed as one part by central management. The operational performance of a retail mall can be maximum if the entire retail area is used effectively and efficiently.

Supporting the case, collaboration can be carried out at the design stage. An example of a design collaboration with facility management. In line with research [23] that collaboration can help in making decisions on business strategies and provide an operational overview of the retail mall business. Besides, facility management can also effectively manage the number of retail space users in the retail business.

The last is related to security and safety in strategic planning for retail property space. Security and safety issues affect the feelings of users/occupant of a retail mall. Consumers cannot enjoy recreational shopping if consumers as the user are concerned about safety from danger and are feeling intimidated. Hedhli et al. [31] agreed that unsafe retail malls can reduce quality and are not suitable places for visitors to gather and connect.

\section{Conclusions}

This study analyzes the relationship between the influence of PBBD application and the strategy for retail property space. Based on the analysis, the study found that the application of PBBD has a positive effect namely, user/occupant interest, building management, and process of design collaboration, 
while risk of loss has a negative effect. This means that if application of PBBD was carried out it will affect increase of the retail property space strategy. The result shows the influence application of PBBD for the effectiveness contributes $44.6 \%$, for profitability contributes $49.4 \%$, for efficiency contributes $61.5 \%$, and overall, the influence of PBBD application for the management retail property space contributes $68.9 \%$.

Finally, this research has limitations which only apply to retail property buildings. Furthermore, research is needed on the development of other types of property such as residential, industrial, etc. Further research also requires a more in-depth analysis of the influence of PBBD on each performance indicator management retail property. This research provides managerial implications by considering the application of PBBD in strategic planning for retail property space. It can contribute to the achievement of high-performance buildings and support sustainable urban development. This research also produces a theoretical understanding of the application of the PBBD concept to retail property, so that it can generate new ideas on how to design optimal retail space management.

Author Contributions: Conceptualization, S.D.A and C.U.; methodology, S.D.A.; writing-original draft preparation, S.D.A; writing-review and editing, C.U., A.F.S., MA.R., N.P.N.; supervision, C.U. All authors have read and agreed to the published version of the manuscript.

Funding: By Grant of “Penelitian Dasar“2020, Ristek/BRIN, Indonesia.

Acknowledgments: DRPM ITS contract number 1132/PKS/ITS/2020.

Conflicts of Interest: The authors declare no conflict of interest.

\section{References}

1. Eckert, A.; He, Z.; West, D.S. An empirical analysis of tenant location patterns near department stores in planned regional shopping centers. J. Retail. Consum. Serv. 2015, 22, 61-70. [CrossRef]

2. Kim, J. A study on the effect that VMD (Visual Merchandising Design) in store has on purchasing products. Int. J. Smart Home 2013, 7, 217-223. [CrossRef]

3. Nourse, H. Measuring business real property performance. J. Real Estate Res. 1994, 9, 431-444.

4. Murray, J.; Elms, J.; Teller, C. Consumer perceptions of higher and lower-level designed store environments. Int. Rev. Retail. Distrib. Consum. Res. 2015, 25, 473-489. [CrossRef]

5. Zhao, M.; Kim, Y.S.; Srebric, J. Occupant perceptions and a health outcome in retail stores. Build. Environ. 2015, 93, 385-394. [CrossRef]

6. Pecoraro, M.; Uusitalo, O. Exploring the everyday retail experience: The discourses of style and design. J. Consum. Behav. 2014, 13, 429-441. [CrossRef]

7. Ceylan, S. A case study on borders in retail spaces. Archnet IJAR Int. J. Arch. Res. 2019, 14, 18-30. [CrossRef]

8. Astarini, S.D.; Utomo, C. Performance-Based Building Design of High-Rise Residential Buildings in Indonesia. Sustainability 2020, 12, 7103. [CrossRef]

9. Wilkinson, S.; Reed, R.; Cadman, D. Property Development, 2th ed.; Routledge: London, UK, 2008; pp. 2-27.

10. Wiegelmann, T.W. Risk Management in the Real Estate Development Industry. Ph.D. Thesis, Institute of Sustainable Development and Architecture, Robina, Australia, 2012.

11. Jagun, Z.T. Risks in feasibility and viability appraisal process for property development and the investment market in Nigeria. J. Prop. Invest. Financ. 2020, 38, 227-243. [CrossRef]

12. Martinez de Salazar, E.; García Sanz-Calcedo, J. Study on the influence of maintenance operations on energy consumption and emissions in healthcare centers by fuzzy cognitive maps. J. Build. Perform. Simul. 2019, 12, 420-432. [CrossRef]

13. Dubois, S.; Maranzana, N.; Gartiser, N.; De Guio, R. A global approach to manage the performance of the problem solving process in innovative design. Int. J. Interact. Des. Manuf. 2017, 11, 351-363. [CrossRef]

14. Ren, Z.; Yang, F.; Bouchlaghem, N.M.; Anumba, C.J. Multi-disciplinary collaborative building designA comparative study between multi-agent systems and multi-disciplinary optimization approaches. Autom. Constr. 2011, 20, 537-549. [CrossRef]

15. Krawinkler, H.; Zareian, F.; Medina, R.A.; Ibarra, L.F. Decision support for conceptual performance-based design. Earthq. Eng. Struc. Dyn. 2006, 35, 115-133. [CrossRef] 
16. Bakens, W.; Foliente, G.; Jasuja, M. Engaging stakeholders in performance-based building: lessons from the Performance-Based Building (PeBBu) Network. Build. Res. Inf. 2005, 33, 149-158. [CrossRef]

17. Duncan, J. Performance-based building: lessons from implementation in New Zealand. Build. Res. Inf. 2005, 3, 120-127. [CrossRef]

18. Yiu, C.Y.; Xu, S.Y. A tenant-mix model for shopping malls. Eur. J. Mark. 2012, 46, 524-541. [CrossRef]

19. Khare, A.; Rakesh, S. Retailing in Indian malls: Antecedents to retailers' preferences for mall-store space. Int. Rev. Retail. Distrib. Consum. Res. 2011, 21, 187-200. [CrossRef]

20. Li, C. A Facility Layout Design Methodology for Retail Environments. Ph.D. Thesis, University of Pittsburgh, Pittsburgh, PA, USA, 2011.

21. Buttle, F. Retail space allocation. Int. J. Phys. Distrib. Mater. Manag. 1984, 14, 3-23. [CrossRef]

22. Edwards, V.; Ellison, L. Corporate Property Management: Aligning Real Estate with Business Strategy; John Wiley \& Sons Inc: Hoboken, NJ, USA, 2009.

23. Chotipanich, S.; Issarasak, S. A study of facility management operation strategy in shopping malls. Prop. Manag. 2017, 35, 236-253. [CrossRef]

24. Soens, M.A.; Brown, R.K. Real Estate Asset Management-Executive Strategies for Profit-Making; John Wiley \& Sons Inc: New York, NY, USA, 1994; pp. 15-19, 277-280.

25. Yiu, C.Y.; Xu, S.Y.; Ng, H.C. Space allocation and tenant placement at high-rise shopping malls. J. Retail. Leis. Prop. 2008, 7, 315-324. [CrossRef]

26. Sim, L.L.; Cheok, R.W. Tenant placement in a Singapore shopping centre. Int. J. Ret. 1989, 17. [CrossRef]

27. Alexander, A.A.; Muhlebach, R.F. Shopping Center Management; Institute of Real Estate Management: Chicago, IL, USA, 1992.

28. Colwell, P.F.; Jackson, C. Modelling rental change across key retail investment markets in Britain. J. Prop. Invest. Financ. 2004, 22, 354-385. [CrossRef]

29. Damian, D.S.; Curto, J.D.; Pinto, J.C. The impact of anchor stores on the performance of shopping centres: the case of Sonae Sierra. Int. J. Retail. Distrib. Manag. 2011, 39, 456-475. [CrossRef]

30. Kent, T. Creative space: Design and the retail environment. Int. J. Retail. Distrib. Manag. 2007, 35, 734-745. [CrossRef]

31. El Hedhli, K.; Chebat, J.C.; Sirgy, M.J. Shopping well-being at the mall: Construct, antecedents, and consequences. J. Bus. Res. 2013, 66, 856-863. [CrossRef]

32. Altuntas, S. A novel approach based on utility mining for store layout: a case study in a supermarket. Ind. Manag. Data Syst. 2017, 117, 304-319. [CrossRef]

33. Mostavi, E.; Asadi, S.; Boussaa, D. Development of a new methodology to optimize building life cycle cost, environmental impacts, and occupant satisfaction. Energy 2017, 121, 606-615. [CrossRef]

34. Baek, E.; Choo, H.J.; Lee, S.H.M. Using warmth as the visual design of a store: Intimacy, relational needs, and approach intentions. J. Bus. Res. 2018, 88, 91-101. [CrossRef]

35. Şener Yılmaz, F. Human factors in retail lighting design: An experimental subjective evaluation for sales areas. Arch. Sci. Rev. 2018, 61, 156-170. [CrossRef]

36. Pukīte, I.; Geipele, I. Different approaches to building management and maintenance meaning explanation. Procedia Eng. 2017, 172, 905-912. [CrossRef]

37. Borkowski, P.; Pawlowski, M.; Makowiecki, T. Economical aspects of building management systems implementation. In Proceedings of the 2011 IEEE Trondheim PowerTech, Trondheim, Norway, 19-23 June 2011.

38. Al-Kasasbeh, M.; Abudayyeh, O.; Liu, H. A unified work breakdown structure-based framework for building asset management. J. Facil. Manag. 2020, 18, 437-450. [CrossRef]

39. Hui, E.Y. Key success factors of building management in large and dense residential estates. Facilities 2005, 23, 47-62. [CrossRef]

40. Xie, X.; Lu, Q.; Rodenas-Herraiz, D.; Parlikad, A.K.; Schooling, J.M. Visualised inspection system for monitoring environmental anomalies during daily operation and maintenance. Eng. Constr. Arch. Manag. 2020, 2, 1835-1852. [CrossRef]

41. Fakhrudin, I.H.; Suleiman, M.Z.; Talib, R. The need to implement Malaysia's Building and Common Property Act 2007 (Act 663) in building maintenance management. J. Facil. Manag. 2011, 9, 170-180. [CrossRef]

42. Détienne, F.; Baker, M.; Burkhardt, J.M. Quality of collaboration in design meetings: Methodological reflexions. CoDesign 2012, 8, 247-261. [CrossRef] 
43. Mcharek, M.; Azib, T.; Hammadi, M.; Larouci, C.; Choley, J.Y. Multidisciplinary design optimization using knowledge management applied to an electronic throttle. COMPEL Int. J. Comput. Math. Electr. Electron. Eng. 2020, 39, 353-362. [CrossRef]

44. Wen, J.; Gheisari, M. Using virtual reality to facilitate communication in the AEC domain: A systematic review. Constr. Innov. 2020, 20, 509-542. [CrossRef]

45. Rahmawati, Y.; Utomo, C.; Zawawi, N.A.W.A. BIM and e-negotiation practices in AEC consulting businesses. Sustainability 2019, 11, 1911. [CrossRef]

46. Ferme, L.; Zuo, J.; Rameezdeen, R. Improving collaboration among stakeholders in green building projects: role of early contractor involvement. J. Leg. Aff. Disput. Resolut. Eng. Constr. 2018, 10, 04518020. [CrossRef]

47. Hadjisophocleous, G.V.; Benichou, N. Performance criteria used in fire safety design. Autom. Constr. 1999, 8, 489-501. [CrossRef]

48. Birkmann, J.; Welle, T. Assessing the risk of loss and damage: exposure, vulnerability and risk to climate-related hazards for different country classifications. Int. J. Glob. Warm. 2015, 8, 191-212. [CrossRef]

49. Penman, T.D.; Eriksen, C.; Blanchi, R.; Chladil, M.; Gill, A.M.; Haynes, K.; Bradstock, R.A. Defining adequate means of residents to prepare property for protection from wildfire. Int. J. Disaster Risk Reduct. 2013, 6, 67-77. [CrossRef]

50. Kobes, M.; Helsloot, I.; De Vries, B.; Post, J.G. Building safety and human behaviour in fire: A literature review. Fire Saf. J. 2010, 45, 1-11. [CrossRef]

51. Tsang, H.H.; Wenzel, F. Setting structural safety requirement for controlling earthquake mortality risk. Saf. Sci. 2016, 86, 174-183. [CrossRef]

52. Sarkar, B.; Saren, S.; Sarkar, M.; Seo, Y.W. A Stackelberg game approach in an integrated inventory model with carbon-emission and setup cost reduction. Sustainability 2016, 8, 1244. [CrossRef]

53. Neuman, W.L. Social Research Methods: Qualitative and Quantitative Approaches, 7th ed.; Pearson Education Limited: London, UK, 2014.

54. Hair, J.F., Jr.; William, C.B.; Babin, B.J.; Rolph, E.A. Multivariate Data Analysis; Pearson Education Limited: New York, NY, USA, 2013.

Publisher's Note: MDPI stays neutral with regard to jurisdictional claims in published maps and institutional affiliations.

(C) 2020 by the authors. Licensee MDPI, Basel, Switzerland. This article is an open access article distributed under the terms and conditions of the Creative Commons Attribution (CC BY) license (http://creativecommons.org/licenses/by/4.0/). 